\title{
Sosyal Bilgiler Dersine İlişkin Araç-Gereç Yeterlikleri Ölçeğinin Geliştirilmesi ve Ortaokul Öğrencilerinin Durumlarının İncelenmesi ${ }^{1}$
}

\author{
Doç. Dr. Hüseyin ÇALIŞKAN \\ Sakarya Üniversitesi, Eğitim Fakültesi, İlköğretim Bölümü, Sakarya / Türkiye \\ Yrd. Doç. Dr. Zafer TANGÜLÜ* \\ Sıtkı Koçman Üniversitesi, Eğitim Fakültesi, İlköğretim Bölümü, Muğla / Türkiye \\ Saliha SEVER \\ Sakarya Üniversitesi, Eğitim Bilimleri Enstitüsü, Sakarya / Türkiye
}

\section{$\ddot{O} \mathbf{z}$}

Bu araştırmada "Sosyal Bilgiler Dersine İlişkin Araç-Gereç Yeterlikleri Ölçeği”nin geliştirilmesi ve ortaokul öğrencilerinin sosyal bilgiler dersine ilişkin araç-gereç yeterlik seviyelerinin çeşitli değişkenlere göre incelenmesi amaçlanmıştır. Araştır-

\footnotetext{
1 Bu çalışmanın bir kısmı 6-8 Haziran 2014 tarihleri arasında düzenlenen ERPA 2014 Uluslararası Eğitim Kongreleri'nde sözlü bildiri olarak sunulmuştur.

*Sorumlu Yazar. Tel: +905335453364Ｅ-posta: zafertangulu@ gmail.com

(C) 2015 Kalem Eğitim ve Sağlık Hizmetleri Vakfi. Bütün Hakları Saklıdır. ISSN: 2146-5606
} 
mada betimsel tarama modeli kullanılmıştır. Açımlayıcı faktör analizleri 426, doğrulayıcı faktör analizleri 138, test-tekrar test güvenirlik analizleri 49 ve durum tespiti için yapılan analizler ise 210 ortaokul öğrencisi üzerinde gerçekleştirilmiştir. Yapılan açımlayıcı faktör analizi sonucunda toplam varyansın \%50.97'sini açıklayan, 20 madde ve dört faktörden oluşan bir ölçme aracı elde edilmiştir. Ölçek maddelerinin faktör yükleri .38 ile .83 arasında değiştiği, madde toplam korelasyonlarının ise .23 ile .57 arasında olduğu ve \%27'lik alt-üst grupların ortalamaları arasındaki farkların anlamlı olduğu belirlenmiştir. Ölçeğin bütünü için hesaplanan iç tutarlılık güvenirlik katsayısının .86 olduğu ve test-tekrar test güvenirlik analizi sonucunda ise ölçeğin genel toplam puan korelasyonunun .95; birinci faktör için .87, ikinci faktör için .84, üçüncü faktör için .87 ve dördüncü faktör için ise .89 olduğu saptanmıştır. Gerçekleştirilen doğrulayıcı faktör analizi sonucunda ki-kare modelinin uyumu $\chi 2=268.88$, $\mathrm{df}=161(\chi 2 / \mathrm{df}=1.67)$ olduğu, uyum indekslerinden RMSEA .06, GFI .90, AGFI .86, TLI .91, CFI .92 ve IFI ise .92 olduğu hesaplanmış ve modelin kabul edilebilir bir uyuma sahip olduğu belirlenmiştir. Ayrıca geliştirilen ölçekle yapılan ölçümler sonucunda ortaokul öğrencilerinin sosyal bilgiler dersine ilişkin araç-gereç yeterlik seviyelerinin iyi seviyede olduğu; cinsiyete göre herhangi bir farklılı̆̆ın olmadığı; sınıf seviyesine göre ise 7. sinıflar aleyhine anlamlı farklılaşmanın olduğu tespit edilmiştir.

Anahtar Kelimeler: Sosyal bilgiler; Araç-gereç; Yeterlik; Ölçek geliştirme.

\title{
Development of Social Studies Lesson Instruments Efficacy Scale and Investigation of Elementary School Students' Situations
}

\begin{abstract}
The aim of the study is to develop "Social Studies Lesson In-struments Efficacy Scale" and to determine elementary school stu-dents' efficacy levels according to different variables. Descriptive survey research design is used in this study. The sample of this study is composed of 426 elementary school students for exploratory factor analysis, 138 elementary school students for confirmatory factor analysis, 49 elementary school students for test-retest reliability analysis and 210 elementary school students for descriptive analysis. The results of
\end{abstract}


exploratory factor analysis revealed an assessment instrument explaining 50.97 percent of total variance and forming 20 items and 4 factors is attained. It is determined that factor loadings of scale items range between .38 and .83 , item-total correlations are between .23 and .57 and 27 percent of difference between subgroup and supergroup averages are significant. It is determined that internal consistency reliability co-efficient calculated for the whole scale is .86 and total point correlation of scale is .95 in the result of test-retest reliability analysis; the first factor is .87 , the second factor is .84 , the third factor is .87 and the fourth factor is .89 . It is determined that the fit of chi-square model in consequence of confirmatory factor analysis is $\chi 2=268.88$, $\mathrm{df}=161(\chi 2 / \mathrm{df}=1.67)$ fit index is calculated RMSEA .06, GFI .90, AGFI .86 , TLI .91, CFI .92, IFI .92 and model has acceptable fit. It is also determined that elementary school students' efficacy levels in social studies lesson instruments are good, there is no difference according to gender, and there is significant difference to the detriment of seventh grade according to class level.

Keywords: Social studies lesson; Instrument; Efficacy; Scale development.

\section{Extended Summery}

\section{Purpose}

The aim of the study is to develop "Social Studies Lesson In-struments Efficacy Scale". Then, elementary school students' efficacy levels in social studies lesson instruments according to gender and class level variables are determined.

\section{Method}

Descriptive survey research design is used in this study. The sample of the study is composed of 426 elementary school students for exploratory factor analysis, 138 elementary school students for con-firmatory factor analysis, 49 elementary school students test-retest reliability analysis and 210 elementary school students for analysis of 
descriptive analysis. An item pool is formed which contains 35 items developed by the researchers. Then, these 35 items are analyzed in terms of intelligibility, appearance and articulation by three lecturers who are expert in their fields and two Social Studies lesson teachers. Lecturers and teachers made essential correction on items. There is an agreement that items have symbolized content. 35 items are reconsti-tuted as 5 point Likert type scale. Statistics programs SPSS 15 and Amos 21 are used in data analysis.

\section{Results}

The result of exploratory factor analysis, an assessment instrument explaining 50.97 percent of total variance and forming 20 items and 4 factors of efficacy for 'map information', for 'material design', for 'technological equipment use' and for 'printed material use' is attained. It is determined that factor loadings of scale items range between .38 and .83 , item-total correlations are between .23 and .57 and .27 percent of difference between subgroup and supergroup averages are significant. It is determined that internal consistency reliability co-efficient calculated for the whole scale is .86 and the first factor is .84 , the second factor is .75 , the third factor is .7 and the fourth factor is .54 and total point correlation of scale is .95 in the result of test-retest reliability analysis; the first factor is .87 , the second factor is .84 , the third factor is .87 and the fourth factor is .89. It is determined that the fit of chi-square model in consequence of confirmatory factor analysis is $\chi 2=268.88, \mathrm{df}=161(\chi 2 / \mathrm{df}=1.67)$ fit index is calculated RMSEA .06, GFI .90, AGFI .86, TLI .91, CFI .92, IFI .92 and model has acceptable fit. It is also determined that elementary school students' efficacy levels 
in social studies lesson instruments are good, there is no difference according to gender, and there is significant difference to the detriment of seventh grade according to class level.

\section{Discussion and Conclusion}

There is a study about development of scale in order to determine elementary school students' efficacy in social studies lesson instru-ments. It is seen that there is no assessment instrument measuring ef-ficacy for equipment used in social studies lesson and providing psy-chometric features. Deficiency of the field is fixed in one sense with this study. Exploratory factor analysis is done for construct validity and it is determined that there are four factors which form items in scale. It is seen that these factors can be named and rounded up. The items are analyzed in terms of their content and features. The first factor in items which are for elementary school students' efficacy in social studies lesson instruments is named as 'map information', the second one is named as 'material design', the third one is named as 'technological equipment use' and the fourth one is named as 'printed material use' in social studies lesson. The fact that 20 items forming scale have high factor loading and others are low shows that these factors are inde-pendent. This is also confirmed with confirmatory factor analysis. As a result of item analysis, it is seen that item-total point correlations of corrected scale are at ideal level. Besides, it is confirmed that t-test results done between 27 percent of subgroup and supergroup have significant difference for all the items and sub-scales. Internal con-sistency reliability coefficient calculated for scale has enough rates in terms of all the scale and factors. It is seen that items in scales are 
consistent and stable with each other and they measure the same structure. So, all the results show that the "equipment efficacy scale for social studies lesson' is homogeneous in terms of measuring the features and all the items in the scale measure the same features. In short, it is seen that this scale is a valid and reliable tool.

The result of measurement done with the scale shows that ele-mentary school students' efficacy levels in social studies lesson in-struments are determined and their situations in terms of some variables (gender and class level) are presented in the study. It is seen that ele-mentary school students' efficacy levels in social studies lesson in-struments are good in general total and in map information and material design. It is also seen that they are average in technological equipment use and printed materials use.

It is indicated that there is no significant difference between el-ementary school students' efficacy scores in social studies lesson in-struments according to gender and average points of total scale and sub-scales in the study. As a result, female and male students' efficacy in social studies lesson instruments has found to be similar.

It is also indicated that there is a significant difference in ele-mentary school students' efficacy levels in social studies lesson in-struments in terms of total scale and all the sub-scales between $6^{\text {th }}$ and $7^{\text {th }}$ grade for the benefit of $6^{\text {th }}$ grade (except for technological equipment use) according to class level variable, there is a significant difference between $5^{\text {th }}$ and $6^{\text {th }}$ grade for the benefit of $6^{\text {th }}$ grade in map information, there is also a significant difference between $5^{\text {th }}$ and $7^{\text {th }}$ 
grade for the benefit of $7^{\text {th }}$ grade in terms of total scale. As a result, the higher are students' class levels, the lower is their efficacy in equipment, map information and material design in social studies lesson.

\section{Giriş}

Eğitim-öğretim ortamlarının verimliliğini artırmada ve eğitim hedeflerinden üst seviyede fayda sağlanmasında ders araç ve gereçlerinin önemli işlevleri bulunmaktadır. Yaşar (2005)'a göre araç kavramının eğitim açısından genelde mekanik nitelikte yardımcı olduğu, gereç kavramının ise daha çok yazılı, basılı nitelikte olduğunu ve araç kaynağın vazgeçilmez ögesi olarak yer aldığını ifade etmiştir. Şimşek (2002) ise eğitim aracını, öğrenme-öğretme etkinlikleri sırasında öğrencinin öğrenmesi ve öğretmenin etkin bir öğretim sağlayabilmesi için bilgilerin kavratılmasında, olayların açıklanmasında, varlıkların tanıtılmasında, üzerinde gözlem ve araştırma yapmada kullanılan her türlü öğretme ve öğrenme yardımcılarıdır, şeklinde tanımlamaktadır. 1960'lara kadar araç ve gereç, eğitimi destekleyen ve kullanımları öğretmenlerin özel istek ve ilgilerine terk edilmiş eğitim yardımcıları olarak görülürken, 1980’lerden itibaren öğrenme-öğretme sistemlerinin vazgeçilmez bir ögesi olarak kabul edilmeye başlamıştır (Alkan, Deryakulu ve Şimşek, 1987). Artık öğrencilere bilgi aktarımı ile ilgili olan anlatım yöntemi öğrencilerin dikkatini uzun süre çekememektedir. Sorun bununla kalmamakta ve bu yöntem sürdürüldüğü takdirde öğrencilerin önceden elde ettikleri bilgiler de unutulmaktadır (Rıza, 1990, s.31). Bu yüzden öğrenmeyi tekdüzelikten kurtarmak için öğretimde araç-gereçler kullanılabilir. 
Araç-gereçler hitap ettikleri duyu organlarına göre görsel (projektör, basılı eğitim araçları, yazı ve gösteri tahtaları, grafikler, haritalar, plan ve krokiler), işitsel (radyo, pikap ve plâklar, teyp, ses bantları, CD ve DVD), görsel-işitsel (film makinesi ve hareketli filmler, televizyon, video, kuklalar, tiyatro, eğitsel geziler), teknoloji destekli araçlar (teleteks ve videoteks uygulamaları, bilgisayar, iletişim uydular1); zihnî farkındalığına göre somut, soyut, somut-soyut araçlar, temin edilebilme özelliklerine göre basit ve öğrenciye yaptırılabilecek, öğretmenin tasarlayıp geliştirebileceği, satın alınabilecek araçlar olarak sinıflandırılır. Öğrenme-öğretme süreçlerinde araç-gereçler genelde öğretimi desteklemek amacıyla kullanılır. İyi tasarlanmış öğretim araç-gereçleri öğretim sürecini zenginleştirir, öğrenmeyi artırır (Yalın, 2007, s.82), öğrencilerin öğrenme-öğretme sürecine katılmalarına ve somut yaşantılar geçirmelerine, anlamlı ve kalıcı öğrenmelerin gerçekleşmesine yardımcı olurlar. Öğretim sürecinde materyal kullanmanın önemli olduğu kadar, önemli bir konuda bu kullanılacak materyalin doğru, etkin ve zamanında kullanılmasıdır. Burada bunu plânlayacak ve etkin olarak kullanacak öğretmene büyük sorumluluklar düşmektedir. Çünkü öğretmen bu değişim ve gelişimi yönetebilecek yegâne unsurdur. Bir anlamda öğretmen işin mutfağındadır ve yüklendiği sorumluluk önemlidir.

Eğitim-öğretim sürecini plânlayan öğretmen farklı ders materyallerini kullanarak dersi ezber ve tek düze olmaktan kurtarmalı ve bu dersin kazanımlarını bireye sağlıklı bir iletişim becerisi yoluyla aktarabilmesi öğretmenden beklenmektedir (Dias ve Atkinson, 2001). 
Ancak burada gözden kaçırılmayacak en önemli hususlardan biri de öğretmenin kullanacağ 1 ders araç-gerecine yönelik bilgi seviyesi ve en önemlisi bu materyallerin kullanılmasının derse olan faydasına inanmasıdır. Böyle bir faydaya inanmayan öğretmen hâliyle ders araç ve gereci kullanmak istemeyecektir (Yalın, 1997). Dersinde araç-gereç kullanımının faydasına inanan öğretmenden ise dersinde kullanacağı araç ve gereçlerin seçimini doğru yapması beklenir. Öğretmen, öğretim hedefleri, öğretim yöntemi, öğrenci özellikleri, öğretmen özellikleri, öğretim ortamının özellikleri, araç-gereç özellikleri ve kısıtlamaları gibi faktörleri hedefe ulaşmada göz ardı edemez. Çünkü bu faktörler birbirlerini etkiler ve birbirlerinden karşılıklı olarak etkilenirler (Çelik, 2007, s.32-33).

Öğretimde kullanılan araç-gereçler, öğrenme-öğretme sürecinin en temel ögeleridir. Öğrencilere kazandırılmak istenilen bilgi, beceri, tutum ve değerleri geliştirmede kullanılan bütün araç, gereç ve kaynaklar öğretim materyali kapsamına girmektedir (Paykoç, 1991). Öğretimde kullanılan araç-gereçler, eğitim ve öğretim etkinliklerinin daha verimli olmasını sağlamada öğretmenlerin en büyük yardımcılarından biridir. Yalın (2008), öğretme sürecinde kullanılan araç ve gereçlerin “Çoklu öğrenme ortamı sağlaması, dikkat çekmesi, hatırlamayı kolaylaştırması, soyut şeyleri somutlaştırması, zamandan tasarruf sağlaması, güvenli gözlem yapma imkânı sağlaması" gibi işlevlerinden dolayı öğretme sürecinde çok önemli olduklarına dikkat çekmektedir. Araç ve gereç kullanımının öğretim üzerindeki bu faydalarının yanında öğrenciler üzerinde de birçok faydası vardır. Kazu ve Yeşilyurt (2008), özellikle öğrencilerin derse olan ilgisini artırmasını, bireysel özellikle- 
rine uygun birçok örnek yapmalarına ve gerçek öğrenme deneyimi yaşamalarına firsatlar sağlamasını, öğrenciyi aktif kılmasını, öğrencilere işbirlikli çalışma imkânı sunmasını ve eleştirel düşünme, problem çözme ve yaratıcı düşünme becerilerinin gelişmesine katkılar sağlamasını araç-gereçlerin öğrenciler açısından önemli faydaları olarak nitelendirmektedir. Ayrıca öğrencilerin soyut kavramları somutlaştırmasına ve öğrenme süresini kısaltarak, zamandan tasarruf sağlamalarına katkılar sağlar (Yazar, 2013). Yeşiltaş (2009) ise araç-gereçlerin öğrenciler açısından içeriği basitleştirerek anlamayı ve hatırlamayı kolaylaştırması, güvenli gözlem yapma imkânı vermesi gibi faydalar1nın olduğunu ifade etmektedir. Bunlardan başka Karataş ve Yapıcı (2006) da araç-gereçlerin öğrencilerin bilgilerini zihinde kodlanmasına, sözcük gelişimine katkıda bulunmasına, öğrenmeyi ilginç hâle getirmesine ve güçlendirmesine ciddi katkılarının olduğunu belirtmişlerdir.

Eğitimde araç-gereç kullanımı, etkili bir öğrenme-öğretme ortamına firsatlar sunarak, öğrencilerin hedeflenen kazanımlardaki becerileri daha kolay gerçekleştirmelerine imkân sağlayarak, programın başarıya ulaşmasında önemli bir rol oynar (Çelik, 2007). Öğretim araç ve gereçleri öğrencilerin bireysel ihtiyaçlarını karşılamasına yardımcı olur. Her öğrencinin öğrenme ihtiyaçları ve öğrenme stilleri farklıdır. Öğrenme stilinin temel varsayımları çok basittir. Öğrenme stili varsayımına göre bütün çocuklar öğrenebilir; fakat çocukların hepsi aynı biçimde öğrenemez. Çocuklar en iyi farklı yollarla öğrenirler ve bütün çocuklara uyan tek bir öğrenme yaklaşımı yoktur. Öğrenmenin tasarlanması ve uygulanmasını farklı öğrenme stillerini dikkate alarak ger- 
çekleştirmek gerekir (Dunn ve Dunn, 2002). Öğretimde kullanılan araç ve gereç sayısı arttıkça, her bir öğrencinin bireysel öğrenme ihtiyaçlarına uygun bir öğretim kanalının bulunması ihtimali de artar. Beynin en iyi çalıştığı zaman; fiziksel yerleri ve maddeleri keşfederek sorular sorup cevapladığı zamandır. Özellikle genç insanlar fiziksel malzemelerle çalışmaktan zevk alır (Gardner, 2006). Eğitimde ders araç-gereçleri ve teknoloji kullanımı eğitim kavramında sözü edilen istendik davranışların kazandırılması için oldukça özenli bir vasıtayı teşkil eder. Bu durum genel manâsıyla eğitimin bütün alanlarını kapsasa da özelde çalışmamıza konu edilen sosyal bilgiler eğitimini de kapsamaktadır. Çünkü günümüzde sosyal bilgiler öğretimi alanı, eğitim süreci olarak değerlendirildiğinde, öğrenme ve öğretme araçları göz önünde bulundurulduğunda defter, kitap ve geleneksel okul öğretim araç-gereçlerinden çok daha fazlasını ifade etmektedir. Bugün sosyal bilgiler eğitimi gerek öğretmen yetiştirmede gerekse bu dersin öğretme sürecinde bireysel eğitim süreçlerinden çoklu ortam öğrenme süreçlerine kadar çok geniş bir yelpazeyi barındıracak etkinlik, öğrenme merhalelerini ve ders materyallerini kapsamaktadır (Welton ve Mallan, 1999). Ders araç ve gereçlerinin bu denli önemli olmasına rağmen ülkemizde hâlen daha eğitim sürecinde ders araçlarından istifade edilme durumu henüz istenilen seviyede değildir (Yazıcı, 2006). Ancak öğrencilerin bu zevki alabilmeleri için de araç ve gereçleri kullanabilme yeterliklerine sahip olması gerekir. Bu bağlamda öğrencilerin dersin öğretimine ilişkin araç-gereçleri kullanımlarının belirlenmesi dersin hedeflerinin gerçekleşme seviyesini tespit etmek açısından önemlidir. Ayrıca bu konu alanına ilişkin daha önce psikometrik özel- 
likleri içeren bir ölçme aracının olmaması ve bu eksiği giderecek bir ölçme aracına duyulan ihtiyaç da önemli görünmektedir. Bu bağlamda araştırma:

1. Ortaokul öğrencilerine yönelik kullanılabilecek "Sosyal Bilgiler Dersine İlişkin Araç-Gereç Yeterlikleri Ölçeği”ni geliştirmek,

2. Geliştirilen bu ölçekle ortaokul öğrencilerinin sosyal bilgiler dersine ilişkin araç-gereç yeterlik seviyelerini belirlemek,

3. Ortaokul öğrencilerinin sosyal bilgiler dersine ilişkin araç-gereç yeterlik düzeylerinin cinsiyetlerine ve sinıf seviyelerine göre farklılılaşıp farklışmadığını tespit etmek amacıyla yapılmıştır.

\section{Yöntem}

\section{Araştırma Modeli}

Araştırma betimsel tarama modelinde yapılandırılan bir çalışmadır. Tarama modelleri, geçmişte ya da günümüzde mevcut olan bir durumu olduğu biçimde betimlemeyi amaçlayan bir araştırma yaklaşımıdır (Karasar, 2005).

\section{Çalışma Grubu}

Araştırmanın çalışma grubunu, Tekirdağ ili Kapaklı ve Saray ilçelerinde bulunan birer ortaokulda, beşinci $(\mathrm{N}=127)$, altıncı $(\mathrm{N}=132)$ ve yedinci $(\mathrm{N}=167)$ sınıflarda öğrenim gören; yaşları 10 ile $14(\overline{\mathbf{X}}=11.96)$ arasında değişen, 203'ü (\%47.7) kız, 223’ü (\%52.3) erkek olmak üzere toplam 426 öğrenci oluşturmaktadır. Deneme maksatlı oluşturulan “Sosyal Bilgiler Dersine İlişkin Araç-Gereç Yeterlikleri Ölçeği” öğrencilere uygulanmış ve elde edilen verilerle açımlayıcı faktör analizi (AFA) gerçekleştirilmiştir. Çalışma grubunu oluşturan sayının belir- 
lenmesi konusunda, Tabachnick ve Fidell (2007)'in faktör analizi için verdiği kriterler dikkate alınmıştır. Tabachnick ve Fidell (2007)'a göre faktör analizi için 300 kişi “iyi”, 500 kişi “çok iyi” ve 1000 kişi “mükemmel" olarak değerlendirilmektedir.

Doğrulayıcı faktör analizleri (DFA) farklı bir çalışma grubu üzerinde gerçekleştirilmiştir. Sakarya ili Serdivan ilçesindeki bir ortaokulda öğrenim görmekte olan yaşları 10 ile $14(\overline{\mathbf{X}}=12.01)$, sınıf seviyeleri beş ile yedinci sınıflar arasında değişen (\%44.2'si beşinci sinıf, \%28.8'i altınc1 sinıf ve \%27.0'si ise yedinci sinif) ve \%54.0'ü erkek, \%46.0'sı kız olan toplam 163 öğrenci üzerinde DFA yapılmıştır.

Ayrıca ölçeğin test-tekrar test güvenirliği, Sakarya ili Serdivan ilçesindeki bir ortaokulda öğrenim görmekte olan yaşları 11 ile 13 arasında $(\overline{\mathbf{x}}=12.00)$, sınıf seviyeleri beş ile yedinci sınıflar arasında değişen (\%24.5'i beşinci sınıf, \%51'i altıncı sınıf ve \%24.5'i yedinci sinıf) ve \%55.1'i erkek, \%44.9’u kız olan toplamda 49 öğrenciye dört hafta ara ile uygulanarak test edilmiştir. Geliştirilen ölçek, Sakarya ili Serdivan ilçesindeki bir ortaokulda öğrenim görmekte olan yaşları 10 ile 14 arasında $(\overline{\mathbf{x}}=12.08)$, sınıf seviyeleri beş ile yedinci sınıflar arasında değişen (\%35.7'i beşinci sınıf, \%34.8'i altıncı sınıf ve \%29.5'i yedinci sınıf) ve \%54.3'ü erkek, \%45.7'si kız olan toplamda 210 kişilik öğrenci grubuna tekrardan uygulanarak ortaokul öğrencilerinin sosyal bilgiler dersine ilişkin araç-gereç yeterlik seviyeleri tespit edilmeye çalışılmıştır.

\section{Veri Toplama Aracı}

Öncelikli olarak ölçeği oluşturacak maddeleri belirlemek ama- 
cıyla ilgili alan yazın taranmış ve kuramsal bilgiler incelenerek elde edilen bilgiler doğrultusunda araştırmacılar tarafından 35 maddelik bir madde havuzu oluşturulmuştur. Yazılan bu ifadelerden taslak bir ölçek formu oluşturulmuştur. Bu ölçek formunun geçerliliği için öncelikli olarak anlaşılırlığını, kapsam ve görünüş geçerliğini değerlendirmek için başvurulacak olan uzmanlar belirlenmiştir. Daha sonraki merhalede ise 35 maddelik taslak ölçek formu sosyal bilgiler eğitimi alanında uzman olan üç öğretim üyesine, iki Türk dili alanı uzmanına ve iki sosyal bilgiler öğretmenine anlaşılabilirlik, görünüş ve ifadelendirmeyi ölçme seviyesi açısından incelettirilmiştir. Öğretmenler, alan uzmanları ve öğretim üyelerinin değerlendirmeleri ve önerileri doğrultusunda maddelerde gerekli düzeltmeler yapılmıştır. Maddelerin kapsamı temsil edebilecek niteliğe sahip olduğu konusunda görüş birliğine varılmıştır. 35 maddelik taslak ölçek formu beş basamaklı likert tipi “Tamamen Kat1liyorum (5), Kat1liyorum (4), Biraz Kat1lyorum (3), Katılmıyorum (2), Hiç Katılmıyorum (1)” bir derecelendirme ölçeği şeklinde yeniden yapılandırılmıştır. Ayrıca ölçeğin başına; ölçeğin amacı, ölçekteki madde sayısı, cevaplama biçimi hakkında bilgi içeren bir yönerge yazılmıştır. Deneme niteliğinde hazırlanan ölçek maddeleri üzerinden 426 öğrenciden elde edilen verilerle geçerlik ve güvenirlik analizleri yapılmıştır.

\section{Verilerin Toplanması ve Analizi}

Öğrencilere yönelik taslak olarak hazırlanan "Sosyal Bilgiler Dersine İlişkin Araç-Gereç Yeterlikleri Ölçeği”nin geçerlik ve güvenirlik sınamasını yapmak amacıyla, ölçek çalışma grubunda betimlenen ortaokul öğrencilerine uygulanmıştır. Uygulama sonucu elde edi- 
len veriler üzerinden geçerlik ve güvenirlik çalışmaları, AFA için SPSS 15 ve DFA için AMOS 21 programları kullanılarak gerçekleştirilmiştir. Geliştirilen ölçek farklı bir araştırma grubuna uygulanarak elde edilen verilerin çözümlenmesinde aritmetik ortalama, standart sapma, ilişkisiz grup t testi, F (varyans) testi, Kruskal Wallis H testi gibi istatistiksel analizlerden yararlanılmıştır. Alt gruplar arasındaki farkl1lığın belirlenmesinde Tukey Çoklu Karşılaştırma Testi yapılmış ve fark testlerindeki anlamlılık $(p<.05)$ olarak kabul edilmiştir. Öğrencilerin sosyal bilgiler dersine ilişkin araç-gereç yeterlik düzeylerinin yorumlanmasında ölçüt olarak 1.00-1.80 “tamamen katılmıyorum”, 1.81-2.60 "kat1lmıyorum", 2.61-3.40 "biraz kat1lyorum", 3.41-4.20 "kat1l1yorum”, 4.21-5.00 "tamamen katılıyorum” aralıkları kullanılmıştır. Ayrıca bütün bu analizlerin yapılmasından önce normallik sınamaları yapılmış ve verilerin normallik sınamasını karşıladığı belirlenmiştir. Ayrıca varyans analizleri için gerekli varsayımlardan biri olan "varyansların homojenliği" testi için ise de Levene testi (Tablo 1) ile incelenerek parametrik ya da non-parametrik testlerin yapılmasına karar verilmiştir.

Tablo 1 incelendiğinde, cinsiyet ve sınıf düzeyi değişkenlerinin homojen bir dağılıma sahip olup olmadıklarını belirlemek amacıyla gerçekleştirilen Levene istatistikleri sonucuna göre, cinsiyet değişkeninin bütün boyutlarda ve sınıf seviyesi değişkeninin "teknolojik araç-gereç kullanımı" ve "basılı materyal kullanımı" boyutlarında varyanslarının homojen olduğu $(p>.05)$; sınıf seviyesinin diğer boyutlarında ve ölçeğin tamamında varyansların homojen dağılmadığı 
114 Doç. Dr. Hüseyin ÇALIŞKAN / Yrd. Doç. Dr. Zafer TANGÜLÜ / Saliha SEVER $(p<.05)$ tespit edilmiştir.

Tablo 1. Ortaokul Öğrencilerinin Sosyal Bilgiler Dersine İlişkin Araç-Gereç Yeterlik Puanlarına Ait Levene F Testi Sonuçları

\begin{tabular}{clcl}
\hline \multirow{2}{*}{ Değişken } & Faktörler & $\begin{array}{c}\text { Levene } \\
\text { İstatistik Değeri }\end{array}$ & $\boldsymbol{p}$ \\
\hline \multirow{5}{*}{ Cinsiyet } & 1.64 & .20 \\
& Harita Bilgisi & .25 & .62 \\
& Materyal Tasarlayabilme & .01 & .91 \\
& Teknolojik Araç-Gereç Kullanabilme & 2.33 & .13 \\
& Basılı Materyal Kullanabilme & 1.89 & .17 \\
\cline { 2 - 3 } Sinıf & Toplam & 13.85 & .00 \\
Düzeyi & Harita Bilgisi & 6.38 & .00 \\
& Teknolojik Araç-Gereç Kullanabilme & 2.27 & .11 \\
& Basılı Materyal Kullanabilme & .59 & .56 \\
& Toplam & 10.81 & .00 \\
\hline
\end{tabular}

Sınıf seviyesi bağlamında, ölçeğin toplamda ve harita bilgisi ve materyal tasarlayabilme boyutlarında varyansların homejen olmaması verilerin farklı sinıf seviyelerinden toplanmasıyla ve toplanan verilerin her bir sınıf seviyesinde yeterli örnekleme sahip olmamasıyla açıklanabilir. Bütün bu sonuçlara göre homojen dağılıma sahip olan değişkenler için parametrik testler, olmayanlar için ise non-parametrik testler kullanılmıştır.

\section{Bulgular}

\section{Birinci Amaca İlişkin Bulgular}

Ortaokul öğrencilerinin sosyal bilgiler dersine ilişkin araç-gereç yeterliklerini belirlemek için geliştirilmek istenen ölçme aracının psikometrik özelliklerini belirleyici istatistiksel analiz bulgularına yer verilmiştir. 
Öncelikli olarak ölçeğin yapısının ortaya çıkarılabilmesi için AFA yapılmıştır. AFA için temel şart olan örneklem büyüklüğünün yeterli olup olmadığına ilişkin Kaiser-Meyer Olkin (KMO) ve verilerin çok değişkenli normal dağılımdan gelip gelmediğini belirlemek amacıyla ise Barlett Küresellik Testi yapılmıştır. Yapılan analiz sonucunda KMO değeri 92 olarak bulunmuş olması bu çalışmanın örneklem büyüklüğünün mükemmele yakın olduğunu göstermektedir (Hutcheson ve Sofroniou, 1999). Ayrıca verilerin çok değişkenli normal dağılımdan gelip gelmediğini kontrol etmek için kullanılan Barlett Küresellik Testi'ne bakılmış ve anlamlı bulunmuştur $(\chi 2=4757.89 ; p<.01)$ KMO testi ölçüm sonucunun .50 ve daha üstü, Barlett Küresellik Testi sonucunun da istatistiksel olarak anlamlı olmasından dolayı verilerin AFA için uygun olduğuna karar verilmiştir (Çokluk, Şekercioğlu ve Büyüköztürk, 2010; Tabachnick ve Fidell, 2007).

"Sosyal Bilgiler Dersine İlişkin Araç-Gereç Yeterlikleri Ölçeği”nin yapı geçerliliği sınaması ve elde edilecek olan yapının daha iyi görülebilmesi için temel bileşenler analizi ve basit bir faktörlendirme elde edebilmek için ise promax döndürme tekniğinden yararlanılmıştır (Çokluk, Şekercioğlu ve Büyüköztürk, 2010).

Yapılan AFA sonucunda toplam varyansın \%50.97'sini açıklayan, 20 madde ve "harita bilgisi", "materyal tasarlayabilme", "teknolojik araç-gereçleri kullanabilme" ve "basılı materyalleri kullanabilme" yeterlikleri olmak üzere dört faktörden oluşan bir ölçme aracı elde edilmiştir. Tek faktörlü desenlerde açıklanan toplam varyansın asgarî \%30 olması yeterli kabul edilebilirken (Büyüköztürk, 2006), çok fak- 
116 Doç. Dr. Hüseyin ÇALIŞKAN / Yrd. Doç. Dr. Zafer TANGÜLÜ / Saliha SEVER

törlü desenlerde ise bu oranın \%41'in üzerinde olması beklenir (Kline, 1994). Buna göre açılklanan toplam varyansın iyi ve yeterli seviyede olduğu söylenebilir. Faktörlere âit bulgular Tablo 2'de verilmiştir.

Tablo 2. Faktör Analizi Sonucunda Maddelere ve Faktörlere İlişki Elde Edilen Bulgular

\begin{tabular}{|c|c|c|c|c|c|c|c|c|}
\hline \multirow{2}{*}{ 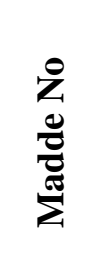 } & \multirow{2}{*}{ 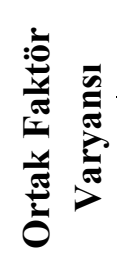 } & \multicolumn{4}{|c|}{$\begin{array}{c}\text { Döndürme Sonrası } \\
\text { Yük Değeri }\end{array}$} & \multirow{2}{*}{ 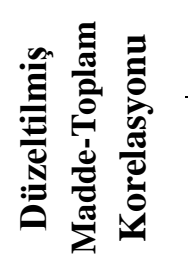 } & \multicolumn{2}{|c|}{ Güvenirlik } \\
\hline & & 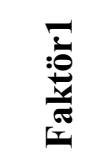 & 产 & 苞 & 苞 & & 包 & 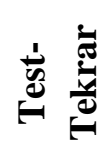 \\
\hline M21 & .55 & .78 & -.11 & .09 & -.10 & .50 & & \\
\hline M19 & .54 & .75 & -.03 & -.01 & .04 & .53 & & \\
\hline M25 & .57 & .74 & .03 & .00 & -.04 & .55 & & \\
\hline M20 & .51 & .71 & .05 & -.06 & .02 & .51 & .84 & .87 \\
\hline M24 & .53 & .67 & .05 & .02 & .05 & .57 & & \\
\hline M26 & .50 & .60 & .18 & .01 & .00 & .57 & & \\
\hline M18 & .47 & .48 & .08 & -.02 & .34 & .54 & & \\
\hline M29 & .58 & .03 & .77 & -.09 & .01 & .50 & & \\
\hline M31 & .45 & -.08 & .71 & .05 & -.12 & .40 & & \\
\hline M35 & .48 & .00 & .68 & -.04 & .07 & .47 & .75 & .84 \\
\hline M32 & .50 & .19 & .62 & -.04 & .07 & .51 & & \\
\hline M28 & .48 & .18 & .53 & .15 & -.09 & .55 & & \\
\hline M16 & .51 & -.04 & -.01 & .72 & .04 & .41 & & \\
\hline M8 & .49 & .19 & -.27 & .71 & -.07 & .33 & & \\
\hline M17 & .51 & .16 & .04 & .65 & -.14 & .47 & .70 & .87 \\
\hline M15 & 49 & -.32 & .23 & .63 & .09 & .33 & & \\
\hline M14 & .45 & .08 & .10 & .47 & .23 & .51 & & \\
\hline M3 & .67 & -.12 & -.13 & .10 & .83 & .23 & & \\
\hline M2 & .62 & .15 & -.08 & -.09 & .78 & .33 & .54 & .89 \\
\hline M4 & .31 & -.06 & .27 & .00 & .38 & .34 & & \\
\hline \multicolumn{2}{|c|}{ Özdeğer } & 5.89 & 1.74 & 1.31 & 1.26 & Ölçeğin & & \\
\hline \multicolumn{2}{|c|}{$\begin{array}{l}\text { Toplam } \\
\text { varyans }\end{array}$} & 29.43 & 8.70 & 6.55 & 6.28 & $\begin{array}{c}\text { güvenirlik } \\
\text { katsayısı }\end{array}$ & .86 & .95 \\
\hline
\end{tabular}


Tablo 2 incelediğinde ölçek maddelerinin yedisinin birinci faktörde (harita bilgisi), beşinin ikinci faktörde (materyal tasarlayabilme), beşinin üçüncü faktörde (teknolojik araç-gereçleri kullanabilme) ve üçünün de dördüncü faktörde (basılı materyalleri kullanabilme) toplandığı görülmektedir. Her bir faktör altında toplanan maddeler içerik ve yapıya uygunluk açısından değerlendirilerek gerekli adlandırmalar yapılmıştır. Ölçeği oluşturan maddelere ilişkin faktör yük değerleri birinci faktör için .48 ile .78 arasında, ikinci faktör için .53 ile .77 arasında, üçüncü faktör için .47 ile .72 arasında ve dördüncü faktör için .38 ile .83 arasında değişmektedir. Bu çok faktörlü yapıdaki her bir maddenin ortak faktör varyansları incelendiğinde değerlerin .31 ile .67 arasında değiştiği görülmektedir. Bu değerlere göre maddelerin homojen bir yapıya sahip oldukları söylenebilir. Elde edilen bütün bu bulgular, ölçeğin tatmin edici düzeyde yapı geçerliği niteliğine kanıt teşkil etmektedir.

Ölçeğin hesaplanan madde-toplam korelâsyonlarına göre maddelerin .23 ile .57 arasında değerler aldığı görülmektedir. Bu değerler 1şığında maddelerin homojen bir niteliğe sahip olduğu ve benzer davranışları temsil ettiği söylenebilir. 20 maddelik ölçeğin Cronbach Alfa (iç tutarlılık) güvenirlik katsayısı .86 olarak bulunmuştur. Ölçekteki maddelerden sıra ile ölçekten çıkarılarak analizler tekrar edilmiş ve her yapılan tekrarda iç tutarlılık katsayısında bir yükselme olmadığından herhangi bir madde ölçekten çıkarılmamıştır (Özdamar, 1997). Yapılan bütün bu güvenirlik işlem sonuçlarına göre ölçeği oluşturan maddelerin birbirleriyle tutarlı olduğu söylenebilir. Ayrıca her bir 
faktörün iç tutarlılık güvenirlik katsayılarını belirlemek için yapılan analiz sonucunda; birinci faktöre ilişkin güvenirlik katsayısı .84, ikinci faktöre ilişkin .75, üçüncü faktöre ilişkin .70 ve dördüncü faktöre ilişkin güvenirlik katsayısı .54 olarak hesaplanmıştır. Dördüncü faktöre ilişkin güvenirlik katsayısının düşük olduğu görülmektedir. Bu durum madde sayısının az olmasından (3 madde) kaynaklanmış olabilir. Ayrıca Kayış (2006) .40-.60 arasındaki güvenirlik katsayısı değerlerinin düşük güvenirlik olarak kabul edilebileceğini belirtmektedir. Ayrıca ölçeğin güvenirliği test-tekrar test güvenirlik belirleme yöntemiyle de test edilmiştir. Dört hafta ara ile iki kez uygulanan ölçeğin genel toplam puan korelasyonunun .95; birinci faktör için .87, ikinci faktör için .84, üçüncü faktör için .87 ve dördüncü faktör için ise .89 olduğu belirlenmiştir. Bu sonuçlara göre ölçeğin güvenilir sonuçlar verdiği söylenebilir.

Ölçeği oluşturan 20 maddenin her birinin madde ayırt edicilik özelliklerini ortaya koyabilmek amaciyla alt ve üst gruplar içinde bulunan öğrencilerin toplam puan ortalamaları t-testi ile her bir madde için karşılaştırılmıştır. Bu durumla ilgili elde edilen sonuçlar Tablo 3 ’te verilmiştir. Tablo 3 incelendiğinde $\% 27^{\prime}$ lik alt ve üst grupların madde puanlarındaki farklara ilişkin t değerlerinin 6.91 ile 15.00 arasında değiştiği ve bütün maddelerin $p<.001$ düzeyinde anlamlı olduğu görülmektedir. Bu sonuca göre de ölçekteki bütün maddelerin benzer davranışları ölçebilecek niteliklere sahip olduğu söylenebilir. Elde edilen yapının yapı geçerliliği ayrıca DFA ile de test edil-miştir. Yapilan analiz sonucunda Ki-kare $(\chi 2)$ modelinin uyumu $\chi 2=268.884$, 
$\mathrm{df}=161(\chi 2 / \mathrm{df}=1.67), p=.00$ 'dir. $\chi^{2} / \mathrm{df}$ 'nin 2 'den küçük olmasından dolayı modelin iyi uyuma sahip olduğu söylenebilir (Hu ve Bentler, 1999; Şimşek, 2007).

Tablo 3. Her Bir Madde İçin Alt ve Üst Grupların Karşılaştırılması

\begin{tabular}{|c|c|c|c|c|c|c|}
\hline \multirow{2}{*}{$\begin{array}{c}\text { Madde } \\
\text { No }\end{array}$} & \multirow{2}{*}{$\mathbf{N}$} & \multicolumn{2}{|c|}{ Alt Grup (\%27) } & \multicolumn{2}{|c|}{ Üst Grup (\%27) } & \multirow{2}{*}{$\mathbf{t}$} \\
\hline & & $\overline{\mathbf{X}}$ & $\mathbf{S}$ & $\overline{\mathbf{X}}$ & $\mathbf{S}$ & \\
\hline M2 & 115 & 2.44 & 1.11 & 3.68 & 1.15 & $8.34 *$ \\
\hline M3 & 115 & 2.16 & 1.10 & 3.33 & 1.45 & $6.91 *$ \\
\hline M4 & 115 & 2.56 & 1.09 & 3.83 & 1.10 & $8.84 *$ \\
\hline M8 & 115 & 2.47 & 1.54 & 4.12 & 1.33 & $8.72 *$ \\
\hline M14 & 115 & 2.30 & 1.28 & 4.43 & .82 & $15.00 *$ \\
\hline M15 & 115 & 2.02 & 1.24 & 3.74 & 1.41 & $9.81 *$ \\
\hline M16 & 115 & 2.28 & 1.47 & 4.38 & 1.09 & $12.36^{*}$ \\
\hline M17 & 115 & 2.70 & 1.51 & 4.54 & .91 & $11.24 *$ \\
\hline M18 & 115 & 2.91 & 1.37 & 4.62 & .63 & $12.10^{*}$ \\
\hline M19 & 115 & 3.10 & 1.34 & 4.72 & .63 & $11.80^{*}$ \\
\hline M20 & 115 & 3.21 & 1.47 & 4.81 & .42 & $11.22 *$ \\
\hline M21 & 115 & 3.25 & 1.44 & 4.77 & .51 & $10.69 *$ \\
\hline M24 & 115 & 2.74 & 1.36 & 4.58 & .73 & $12.84^{*}$ \\
\hline M25 & 115 & 2.74 & 1.48 & 4.75 & .60 & $11.56^{*}$ \\
\hline M26 & 115 & 2.89 & 1.34 & 4.72 & .55 & $13.60^{*}$ \\
\hline M28 & 115 & 2.75 & 1.77 & 4.64 & .66 & $14.19^{*}$ \\
\hline M29 & 115 & 2.77 & 1.27 & 4.60 & .67 & $13.67 *$ \\
\hline M31 & 115 & 2.54 & 1.31 & 4.19 & 1.04 & $10.57 *$ \\
\hline M32 & 115 & 2.74 & 1.35 & 4.55 & .70 & $12.73^{*}$ \\
\hline M35 & 115 & 3.04 & 1.45 & 4.73 & .60 & $11.56^{*}$ \\
\hline
\end{tabular}

Önemli indekslerden bir olan RMSEA değerinin .064 olduğu belirlenmiştir. RMSEA değerinin .08'den düşük çıkması kabul edilebilir uyuma işarettir (Hu ve Bentler, 1999; Şimşek, 2007). Diğer model 
uyum değerleri GFI .90, AGFI .86, TLI .91, CFI .92 ve IFI ise .92 olarak tespit edilmiştir. Ayrıca modele ilişkin bu yapı elde edilirken düzeltme indeksleri dikkate alınmıştır. $\chi 2$ değerine ve model uyumuna önemli ölçüde katkı sağlayan 15 ile 16, 29 ile 35 ve 18 ile 25 maddeleri arasında ilişkilendirmeler yapılmıştır. Bu maddelerin aynı faktör yapısı içerisinde benzer davranışları ölçtükleri için hata varyanslarında ilişki çıtığ 1 söylenebilir. Cole (1987) ve Gerbing ve Anderson (1993) model uyum değerlerinin bazılarının .80 üzerine çıkmasının da kabul edilebilir alt sınırlar olarak değerlendirilebileceğini ifade etmişlerdir. Bütün bu model uyum değerlerine göre de ölçeğinin kabul edilebilecek düzeyde bir model niteliği taşıdığı söylenebilir. Modele ait path diagramı Şekil 1'de verilmiştir.

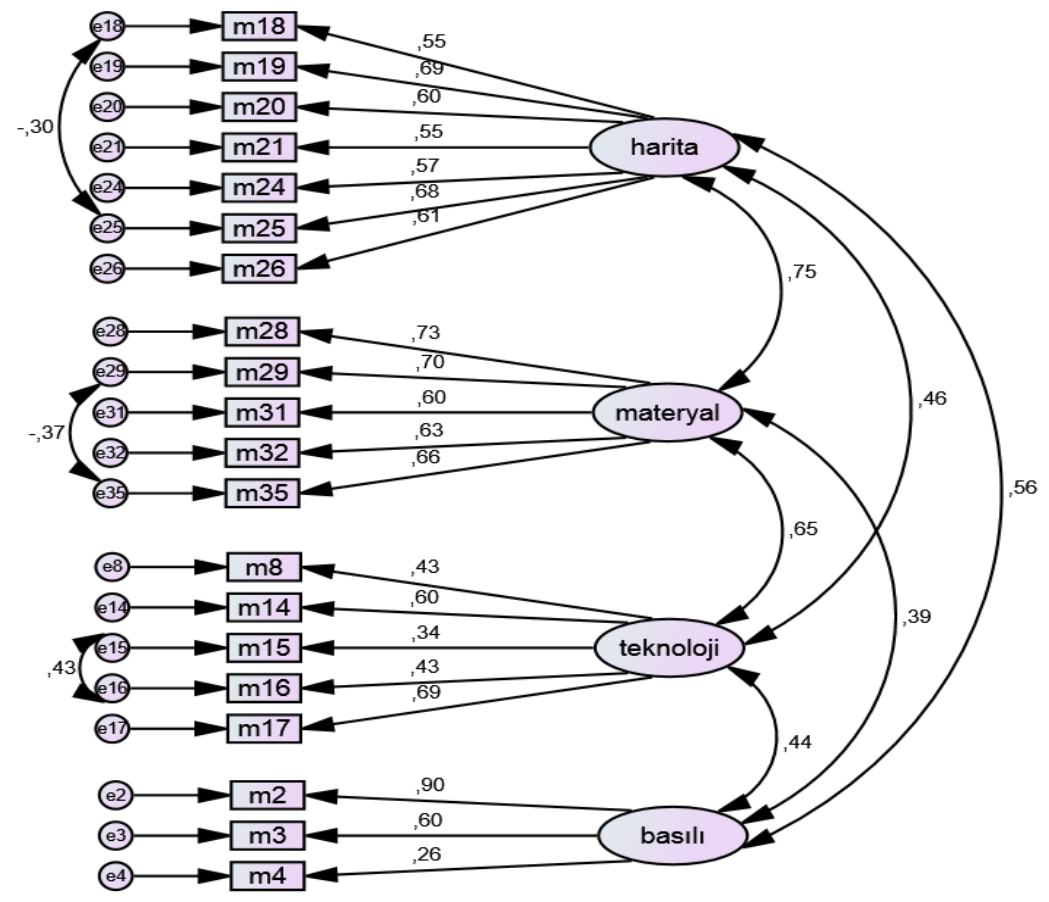

Şekil 1. Sosyal Bilgiler Dersine İlişkin Araç-Gereç Yeterlikleri Ölçeği'nin Path Diagramı 


\section{İkinci ve Üçüncü Amaca İlişkin Bulgular}

Ortaokul öğrencilerinin sosyal bilgiler dersine ilişkin araç-gereç yeterlik düzeyleri ve bu yeterlik düzeylerinin cinsiyete ve sınıf seviyelerine göre anlamlı bir farklılık gösterip göstermediğini belirlemek için yapılan analizlere âit bulgulara aşağıda yer verilmiştir.

Tablo 4. Ortaokul Öğrencilerinin Sosyal Bilgiler Dersine İlişkin Araç-Gereç Yeterlik Seviyeleri

\begin{tabular}{lccc}
\hline Boyutlar & $\mathbf{N}$ & $\overline{\mathbf{X}}$ & $\mathbf{S}$ \\
\hline (F1)Harita Bilgisi & 210 & 3.85 & .90 \\
(F2)Materyal Tasarlayabilme & 210 & 3.62 & .99 \\
(F3)Teknolojik Araç-Gereçleri Kullanabilme & 210 & 2.89 & .98 \\
(F4)Bas1lı Materyalleri Kullanabilme & 210 & 3.37 & .95 \\
Toplam & 210 & 3.48 & .74 \\
\hline
\end{tabular}

F1:Faktör1; F2:Faktör2; F3:Faktör3; F4:Faktör4

Tablo 4 incelendiğinde ortaokul öğrencilerinin "Sosyal Bilgiler Dersine İlişkin Araç-Gereç Yeterlik Ölçeği”ne verdikleri cevaplar dikkate alındığı zaman ölçekte yer alan dört boyuttan öğrenciler kendilerini sırasıyla harita bilgisi (3.85), materyal tasarlayabilme (3.62) ve ölçeğin tamamında kendilerini "katılıyorum" seviyesinde yeterli bulduklar1; teknolojik araç-gereç kullanabilme (2.89) ve basılı materyalleri kullanabilmede (3.37) ise "biraz katılıyorum" seviyesinde yeterli buldukları görülmektedir. Ayrıca ölçeğin bütün alt boyutlarının standart sapma değerlerinin birbirine oldukça yakın olduğu, buna göre de her bir alt boyutta öğrencilerin birbirine benzer tepkiler verdikleri söylenebilir. Bütün bu sonuçlara göre harita bilgisi, materyal tasarlayabilme ve 
toplam ölçek için öğrencilerin büyük oranda sosyal bilgiler dersine ilişkin araç-gereç yeterliklerinin iyi olduğu; teknolojik araç-gereçleri kullanabilme ve basılı materyalleri kullanabilme yeterliklerinin ise diğerlerine göre düşük olduğu söylenebilir.

Tablo 5. Ortaokul Öğrencilerinin Sosyal Bilgiler Dersine İlişkin Araç-Gereç Yeterlik Puanlarının Cinsiyete Göre T-Testi Sonuçları

\begin{tabular}{|c|c|c|c|c|c|c|}
\hline Boyutlar & Cinsiyet & $\mathbf{N}$ & $\overline{\bar{X}}$ & $\mathbf{S}$ & $\mathbf{t}$ & $p$ \\
\hline \multirow{2}{*}{ Harita Bilgisi } & $\mathrm{K} 1 \mathrm{Z}$ & 96 & 3.86 & .81 & \multirow{2}{*}{.16} & \multirow{2}{*}{.87} \\
\hline & Erkek & 114 & 3.84 & .97 & & \\
\hline \multirow{2}{*}{ Materyal Tasarlayabilme } & Kiz & 96 & 3.62 & 1.05 & \multirow{2}{*}{.08} & \multirow{2}{*}{.93} \\
\hline & Erkek & 114 & 3.63 & .94 & & \\
\hline Teknolojik Araç-Gereçleri & $\mathrm{K}_{1 \mathrm{Z}}$ & 96 & 2.89 & .97 & \multirow{2}{*}{.01} & \multirow{2}{*}{.99} \\
\hline Kullanabilme & Erkek & 114 & 2.89 & .99 & & \\
\hline Basılı Materyalleri & Kiz & 96 & 3.40 & .89 & \multirow{2}{*}{.44} & \multirow{2}{*}{.66} \\
\hline Kullanabilme & Erkek & 114 & 3.35 & .99 & & \\
\hline \multirow{2}{*}{ Toplam } & $\mathrm{K} 1 \mathrm{z}$ & 96 & 3.49 & .70 & \multirow{2}{*}{.13} & \multirow{2}{*}{.90} \\
\hline & Erkek & 114 & 3.48 & .78 & & \\
\hline
\end{tabular}

Tablo 5 incelendiğinde ortaokul öğrencilerinin sosyal bilgiler dersine ilişkin araç-gereç yeterlik puanlarının cinsiyete göre toplam ölçek ve alt boyutlar bazında (harita bilgisi, materyal tasarlayabilme, teknolojik araç-gereçleri kullanabilme ve basılı materyalleri kullanabilme) anlamlı bir farklılaşmanın olmadığı görülmektedir ( $p>.05) . \mathrm{Bu}$ bulgulara göre kız ve erkek öğrenciler araç-gereç kullanım yeterlikleri açısından birbirleri ile aynı özelliklere sahip oldukları şeklinde yorumlanabilir. 
Tablo 6. Ortaokul Öğrencilerinin Sosyal Bilgiler Dersine İlişkin Araç-Gereç Yeterlik Puanlarının Sınıf Seviyesine Göre ANOVA Sonuçları

\begin{tabular}{lccccccc}
\hline Boyutlar & Gruplar & $\mathbf{N}$ & $\bar{X}$ & S & F & p & Fark \\
\hline Teknolojik & 5. Sinff & 75 & 3.02 & 1.07 & & & \\
Araç-Gereçleri & 6. Snnıf & 73 & 2.96 & .95 & 3.02 & .051 & - \\
Kullanabilme & 7. Sinıf & 62 & 2.64 & .85 & & & \\
Basilı & 5. Sinıf & 75 & 3.41 & .98 & & & \\
Materyalleri & 6. Sinıf & 73 & 3.59 & .75 & 4.77 & .004 & 6.-7. \\
Kullanabilme & 7. Sinıf & 62 & 3.07 & 1.03 & & & Sinıf \\
\hline
\end{tabular}

Tablo 6 incelendiğinde, ortaokul öğrencilerinin sosyal bilgiler dersine ilişkin araç-gereç yeterlik puanlarının sınıf seviyesine göre teknolojik araç-gereçleri kullanabilme ortalama puanlarında anlamlı bir farkl11ık görülmez iken ( $p>.05)$; basılı materyalleri kullanabilme boyutunda ise anlamlı bir farklılık oluşturduğu görülmektedir ( $p<.05)$. Çoklu karş̧laştırma testlerinden Tukey ile yapılan analiz sonucunda, ortaokul öğrencilerinin sosyal bilgiler dersinde basılı materyalleri kullanabilme yeterliklerinin arasında ortaya çıkan bu farklılığın altı ile yedinci sınıflar arasında altıncı sınıflar lehine ortaya çıktığı görülmüştür.

Tablo 7 incelendiğinde ortaokul öğrencilerinin sosyal bilgiler dersine ilişkin araç-gereç yeterlik puanlarının sınıf seviyesine göre ölçeğin tamamında ve harita bilgisi ve materyal tasarlayabilme boyutlarında anlamlı bir farklılık oluşturduğu görülmektedir $(p<.01)$. Farkların kaynağını belirlemek için ikili kombinasyonlar üzerinden gerçekleştirilen Mann Whitney U Testi sonucunda, ölçeğin tamamında ve 
harita bilgisi ve materyal tasarlayabilme boyutlarında ortaya çıkan farklılı̆ğn altıncı sınıf ile yedinci sınıf arasında altıncı sınıflar lehine ortaya çıktığ 1 belirlenmiştir.

Tablo 7. Ortaokul Öğrencilerinin Sosyal Bilgiler Dersine İlişkin Araç-Gereç Yeterlik Puanlarının Sınıf Seviyesine Göre Kruskal Wallis Sonuçları

\begin{tabular}{llccccc}
\hline Boyutlar & Gruplar & $\mathbf{N}$ & Sira Ort. & $\boldsymbol{\chi 2}$ & $\boldsymbol{p}$ & Fark \\
\hline \multirow{2}{*}{ Harita } & 5. Sinif & 75 & 101.51 & & & \\
Bilgisi & 6. Sinif & 73 & 125.52 & 14.21 & .00 & 5.-6. Sinif \\
& 7. Sinif & 62 & 86.75 & & & \\
Materyal & 5. Sinif & 75 & 107.78 & & & \\
Tasarlaya- & 6. Sinif & 73 & 118.91 & 9.49 & .00 & 6.-7. Sinif \\
bilme & 7. Sinif & 62 & 86.95 & & & \\
& 5. Sinif & 75 & 107.43 & & & \\
Toplam & 6. Sinif & 73 & 123.01 & 15.00 & .00 & 5.-7. Sinif \\
& 7. Sinif & 62 & 82.54 & & & 6.-7. Sinif \\
\hline
\end{tabular}

Ayrıca ölçeğin tamamında beşinci sınıf ile yedinci sınıf arasında yedinci sınıflar aleyhine ve harita bilgisi boyutunda beşinci sınıf ile altıncı sınıf arasında beşinci sınıflar lehine anlamlı farklılığın olduğu belirlenmiştir. Bu bulgulara göre, ortaokul öğrencilerinin sosyal bilgiler dersine ilişkin araç-gereç yeterlikleri toplamında ve harita bilgisi ve materyal tasarlayabilme yeterliklerinin sınıf seviyesi yükseldikçe azaldığg söylenebilir.

\section{Tartışma, Sonuç ve Öneriler}

Araştırmada öncelikli olarak ortaokul öğrencilerinin sosyal bilgiler dersinde kullanılan araç-gereçlere ilişkin yeterliklerinin belirlenmesi için bir ölçek geliştirme çalışması yapılmıştır. Alan-yazın 
incelendiğinde, ortaokul öğrencilerinin sosyal bilgiler dersinde kullanılan araç-gereçlere ilişkin yeterliklerini ölçmeye dönük psikometrik özellikleri karşılayan herhangi bir ölçme aracının olmadığg görülmüştür. Yapılan çalışma ile bu alandaki yaşanan eksiklik bir anlamda giderilmeye çalışılmıştır.

İlk önce ilgili literatürden, uzman ve öğretmen görüşlerinden faydalanılarak 35 maddelik, 5'li Likert tipli bir ölçek hazırlanmıştır. Hazırlan ölçek uzmanlar tarafından anlaşılırlığı, kapsam ve görünüş geçerliği açılarından incelenmiştir. Gelen dönütler doğrultusunda gerekli düzeltme işlemlerinden sonra 35 maddelik ölçeğin yapı geçerlilik çalışmalarına geçilmiştir.

Yapı geçerliği için AFA yapılmış ve ölçeği oluşturan maddelerinin dört faktörde toplandığı belirlenmiştir. $\mathrm{Bu}$ faktörlerin adlandırılabilinir ve toplanabilir bir yapıya sahip olduğu görülmüştür. İçerik ve özellikleri bakımından faktörlerde bulunan maddeler incelenmiştir. Buna göre, ortaokul öğrencilerinin sosyal bilgiler dersine ilişkin araç-gereç yeterliklerine yönelik birinci faktördeki maddeler "harita bilgisi", ikinci faktördeki maddeler "materyal tasarlayabilme", üçüncü faktördeki maddeler "teknolojik araç-gereçleri kullanabilme" ve dördüncü faktördeki maddeler "basılı materyalleri kullanabilme" şeklinde adlandırılmıştır. Ölçeği oluşturan 20 maddenin bütününün kendi faktörlerinde faktör yük değerlerinin yüksek, diğer faktörlerde ise düşük olması bu faktörlerin bağımsızlığının göstergesi olarak kabul edilmiştir. Elde edilen bu yapı, aynı zamanda DFA ile de teyit edilmiştir. 
Gerçekleştirilen madde analizi sonucunda ölçeğin düzeltilmiş madde-toplam puan korelasyonlarının ideal seviyede olduğu görülmüştür. Ayrıca \%27'lik alt ve üst grup puanları arasında yapılan $t$ testi sonuçlarına göre bütün maddeler ve alt ölçekler için anlamlı bir farklıl1k olduğu tespit edilmiştir. Ölçek için hesaplanan iç tutarlılık güvenirlik katsayılarının hem ölçeğin bütününde hem de faktörler bazında yeterli seviyede değerlere sahip olması, ölçekte yer alan maddelerin birbirleri ile tutarlı olduğunu ve kararlılıkla aynı yapıyı ölçtüğünü ortaya koymuştur. Dolayısıyla tüm bu sonuçlar "Sosyal Bilgiler Dersine İlişkin Araç-Gereç Yeterlik Ölçeği”nin ölçtüğü özellikler bakımından homojen olduğuna ve ölçekteki bütün maddelerin aynı özelliği ölçtügüne (Tavşancıl, 2002) birer delil teşkil etmiştir. Kısacası geliştirilen bu ölçeğin geçerli ve güvenilir bir araç olduğunu göstermektedir. Bu bağlamda geliştirilen bu ölçek ortaokul öğrencilerinin sosyal bilgiler dersine ilişkin araç-gereç yeterlik düzeylerini belirlemek için yapılacak olan bundan sonraki araştırmalarda kullanılabilir. Aynı zamanda her bir boyut daha ayrıntılı bir şekilde incelenerek diğer derslerle ilgili araç-gereç yeterlikleri açısından karşılaştırılarak aralarında fark olup olmadığını belirlemeye yönelik çalışmalar yapılabilir.

Araştırmada ayrıca geliştirilen ölçekle yapılan ölçümler sonucunda ortaokul öğrencilerinin sosyal bilgiler dersine ilişkin araç-gereç yeterlik seviyeleri belirlenmiş ve bazı değişkenlere (cinsiyet ve sınıf seviyesi) göre durumları ortaya konmuştur. Buna göre ortaokul öğrencilerinin sosyal bilgiler dersine ilişkin araç-gereç yeterlik seviyelerinin genel toplamda ve harita bilgisi ile materyal tasarlayabilme boyutlarında iyi düzeyde olduğu, teknolojik araç-gereçleri kullanabilme ve 
basılı materyalleri kullanabilme yeterliklerinin ise orta düzeyde olduğu belirlenmiştir.

Nitekim bu sonucu Karaca (2011)'de ortaya koymuştur. İlgili çalışma da ilköğretim öğretmenlerinin ders işlerken ağırlıklı olarak ders kitapları ve tebeşirli yazı tahtalarını kullandığı sonucu ders araç-gereç kullanımındaki yetersiz seviyeyi bir kez daha gözler önüne sermiştir. Fidan (2008)'de yaptığ öğretmen görüşlerini sorgulamış ve öğretmenlerin teknoloji kullanımına ilişkin olumlu tutumlar gösterdiği sonucuna ulaşmıştır. Ancak öğretmenlerin derste araç-gereç kullanımını engelleyen değişkenlerin, bölgesel farklılıkların ve ekonomik faktörlerin varlığ 1 da madalyonun diğer bir yüzünü oluşturmuştur. Ulusoy ve Gülüm (2009) tarafindan Adıyaman ilindeki sosyal bilgiler öğretmenlerinin tarih ve coğrafya konularını işlerken kullandıkları araç-gereçler ve bu araç-gereçlere ulaşım durumlarıyla ilgili yapılan çalışma bu durumu örnekler niteliktedir. Çalışma Adıyaman ilindeki sınıf ve sosyal bilgiler öğretmenlerinin tarih ve coğrafya konularını işlerken materyal kullanmada istekli olduklarını ancak kullanacakları materyallerin yetersiz olduğunu, materyal eksiklikleri yaşadıklarını açıkca ortaya koymuştur. Çalışmamızın sonuçları Ulusoy ve Gülüm (2009)'un çalışması ile paralellik göstermektedir.

Bir diğer önemli konu da öğretmenlerin ders araç-gereçlerini ne amaçla kullandıklarını bilmektir. Bu konuda Kazu ve Yeşilyurt (2008) tarafından yapılan araştırmada; öğretmenlerin öğrencilerden yüksek derecede başarı elde etmek isteme, öğrencilere daha fazla bilgi ve be- 
ceri kazandırma, derslerin verimini artırma ve işlenmesini zevkli hâle getirme, öğrenme-öğretme süreçlerine çeşitlilik, renklilik ve değişiklik katma, gerçek hayatı derslere yansıtma, öğrencilerin yaparak ve yaşayarak öğrenmesine katkı sağlama, motivasyon ve dikkatini artırma, kalıcı öğrenmelerine yardımcı olma ve bilgi ihtiyacını karşılama amaçlarını gerçekleştirmek için kullandıkları tespit edilmiştir. Genç (2012)'de öğretmen adaylarının ders araç kullanma durumu üzerine yaptığ çalışmada üniversitelerin eğitim fakültelerinde teknoloji kullanımına daha fazla önem vermesi gerektiği ve müfredatın teknolojik yeterliklerle tekrardan düzenlenmesi gerektiği sonucuna ulaşmıştır.

Araştırmada ortaokul öğrencilerinin sosyal bilgiler dersine ilişkin araç-gereç yeterlik puanlarının cinsiyete göre toplam ölçek ve ölçeğin alt boyutları ortalama puanları arasında anlamlı bir farklılığın olmadığı sonucu elde edilmiştir. Yani kız ve erkek öğrencilerin sosyal bilgiler dersinde araç-gereç kullanımına yönelik yeterliklerinin aynı özellikte olduğu sonucu elde edilmiştir. İlgili alan yazınına baktığımızda yapılan çalışmalar genelde öğretmen ve öğretmen adaylarına yönelik yapılmiştır.

Sınıf seviyesi değişkenine göre ise ortaokul öğrencilerinin sosyal bilgiler dersine ilişkin araç-gereç yeterlik seviyelerinin toplam ölçek ve bütün alt boyutlarda (sadece teknolojik araç-gereç kullanabilme hariç) altı ile yedinci sınıflar arasında altıncı sınıflar lehine anlamlı farklıkların olduğu; harita bilgisi boyutunda ise beş ile altıncı sınıflar arasında yine altıncı sınıflar lehine bir farklılığın olduğu; ayrıca toplam ölçek bazında beş ile yedinci sınıflar arasında beşinci sınıflar lehine anlamlı 
bir farklılık olduğu yönünde sonuçlar elde edilmiştir.

Sonuç olarak sosyal bilgiler öğretiminde ders araç-gereçlerinin kullanımına yönelik ilgili alan-yazınına baktığımızda bu yönde yapılmış olan çalışmalar daha sonraki araştırmalara ve ders öğretmenleri ile öğretmen adaylarına kaynak teşkil edeceği şüphesizdir.

\section{Kaynakça}

Alkan, C., Deryakulu, D. ve Şimşek, N. (1987). Eğitim teknolojisi. Eskişehir Anadolu Üniversitesi Açıköğretim Fakültesi Yayınları.

Büyüköztürk, Ş. (2006). Sosyal bilimler için veri analizi el kitabı. Ankara: Pegem A Yayıncılık.

Cole, D. A. (1987). Utility of confirmatory factor analysis in test validation research. Journal of Consulting and Clinical Psychology, 55(4), 584-594.

Çelik, L. (2007). Öğretim materyallerinin hazırlanması ve seçimi. Ö. Demirel, (Ed.), Öğretim teknolojileri ve materyal tasarımı içinde (29-68). Ankara: Pegem A Yayıncılik.

Çokluk, Ö., Şekercioğlu, G. ve Büyüköztürk, Ş. (2010). Sosyal bilimler için çok değişkenli istatistik, SPSS ve LISREL uygulamaları. Ankara: Pegem Akademi.

Dias, B. L. ve Atkinson, S. (2001). Technology integration: Best practices-where do teachers stand? International Electronic Journal for Leadership in Learning, 5(11), 11 Ekim 2014 http://iejll.synergiesprairies.ca/iejll/index.php/ijll/article/view/50 $3 / 165$.

Dunn, R. S. ve Dunn, K. (2002). The Dunn and Dunn learning styles model of instruction. 3 Temmuz 2014, 
http://wps.prenhall.com/wps/media/objects/863/884633/Volume _medialib /dunn.pdf

Fidan, N. K. (2008). İlköğretimde araç gereç kullanımına ilişkin öğretmen görüşleri, Kurumsal Eğitimbilim, 1(1), 48-61.

Gardner, H. (2006). Eğitimli akıl-olayların ve standart testlerin ötesinde, her çocuğun hak ettiği ĕgitim sistemi. (Ö. Akbaş, Çev.). İstanbul: Morpa Yayıncılık. (Orijinal çalışma basım tarihi 1 Eylül 2000)

Genç, M. (2012). Aday öğretmenlerin ders araç gereçlerini kullanma durumları üzerine bir araştırma. The Journal of Academic Social Science Studies, 5(7), 347-355.

Gerbing D. W. ve Anderson J. C. (1993). Monte Carlo evaluations of the goodness-of-fit indices for structural equation models. K. A. Bollen ve J. S. Long, (Ed.), Testing structural equation models içinde (40-65). Newbury Park, CA: Sage.

Hu, L. T. ve Bentler, P. M. (1999). Cut off criteria for fit indexes in covariance structure analysis: Conventional criteria versus new alternatives. Structural Equation Modeling, 6(1), 1-55.

Hutcheson, G. ve Sofroniou, N. (1999). The multivariate social scientist: Introductory statistics using generalized linear models. Thous and Oaks, CA: Sage Publications.

Karaca, F. (2011). İlköğretim öğretmenleri derslerinde ne tür öğretim araç ve gereçleri kullanmaktadır? Selçuk Üniversitesi Ahmet Keleşoğlu Eğitim Fakültesi Dergisi, 32, 131-148.

Karataş, S. ve Yapıc1, M. (2006). Öğretim teknolojileri ve materyal geliştirme dersinin işlenişi ve uygulama örnekleri. Afyon Kocatepe Üniversitesi Sosyal Bilimler Dergisi, 8(2), 311-325. 
Karasar, N. (2005). Bilimsel araştırma yöntemi: Kavramlar, ilkeler, teknikler. Ankara: Nobel Yayın Dağıtım.

Kayış, A. (2006). Güvenirlik analizi. S. Kalayci, (Ed.), SPSS uygulamalı çok değişkenli istatistik teknikleri (2. baskı) içinde (403-419). Ankara: Asil Yayın Dağıtım.

Kazu, H. ve Yeşilyurt, E. (2008). Öğretmenlerin öğretim araç-gereçlerini kullanım amaçları. Fırat Üniversitesi Sosyal Bilimler Dergisi, 18(2), 175-188.

Kline, P. (1994). An easy guide to factor analysis. London: Routledge.

Özdamar, K. (1997). Paket programlar ile istatistiksel veri analizi, Eskişehir: Anadolu Üniversitesi Yayınları.

Paykoç, F. (1991). Tarih öğretimi. Eskişehir: A.Ü. Açık öğretim Fakültesi Yayınları.

Rıza, E. T. (1990). Eğitimde yöntemler teknolojisi. İzmir: Karınca Matbaas1.

Tabachnick, B. G. ve Fidell, L. S. (2007). Using multivariate statistics (5. bask1). Londra: Pearson Education. Inc.

Tavşancıl, E. (2002). Tutumların ölçülmesi ve SPSS ile veri analizi. Ankara: Nobel Yayınları.

Ulusoy, K. ve Gülüm, K. (2009). Sosyal bilgiler dersinde tarih ve coğrafya konuları işlenirken öğretmenlerin materyal kullanma durumları. Ahi Evran Üniversitesi Eğitim Fakültesi Dergisi, 10(2), 85-99.

Welton, D. A. ve Mallan, J. T. (1999). Children and their world strategies for teaching social studies. Boston: Houghton Mifflin Co. 
Yalın, H. İ. (1997). Eğitim teknolojisi öğretim tasarımı. Ankara: Pegem Yayınevi.

Yalın, H. İ. (2007). Öğretim teknolojileri ve materyal geliştirme. Ankara: Nobel Yayın Dağıtım

Yalın, H. İ. (2008). Öğretim teknolojileri ve materyal geliştirme (20. baskı). Ankara: Nobel Yayın Dağıtım.

Yaşar, Ş. (2005). Öğretimde araç ve gereç kullanımı. M. Gültekin, (Ed.), Öğretimde planlama ve değerlendirme içinde (143-160). Eskişehir: Anadolu Üniversitesi Yayınları.

Yazar, İ. (2013). Öğretim yöntemleri ve materyal geliştirme ders notları. 4 Eylül 2014, http://web.deu.edu.tr/ilyas/Courses/otmg/OTMT.pdf.

Yazıc1, K. (2006). Sosyal bilgilerde kullanılan görsel araçlar: Haritalar-küreler, resimler, tablolar ve grafikler. Selçuk Üniversitesi Soysal Bilimler Enstitüsü Dergisi, 15, 651-662.

Yeşiltaş, E. (2009). Sosyal bilgiler öğretiminde öğretim materyalleri ve teknolojileri. M. Safran, (Ed.), Sosyal bilgiler öğretimi (225-241). Ankara: Pegem Akademi.

Şimşek, N. (2002). Derste eğitim teknolojisi kullanımı. Ankara: Nobel Yayıncilı.

Şimşek, Ö. F. (2007). Yapısal eşitlik modellemesine giriş: Temel ilkeler ve LISREL uygulamaları. Ankara: Ekinoks Yayınları. 